Supporting information for

\title{
A Comprehensive Review on Exploration and Drilling Techniques for Natural Gas Hydrate Reservoirs
}

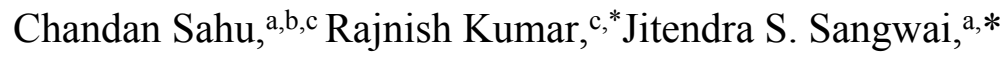 \\ ${ }^{a}$ Gas Hydrate and Flow Assurance Laboratory, Petroleum Engineering Program, \\ Department of Ocean Engineering, Indian Institute of Technology Madras, \\ Chennai 600 036, India \\ ${ }^{b}$ Department of Chemical Engineering, Indian Institute of Technology Madras, Chennai 600 \\ 036, India \\ ${ }^{c}$ School of Petroleum Technology, Pandit Deendayal Petroleum University, Raisan, \\ Gandhinagar, Gujarat, 382007, India
}

\section{Corresponding Authors:}

Rajnish Kumar: rajnish@,iitm.ac.in

Jitendra Sangwai: jitendrasangwai@iitm.ac.in 


\section{Table S1}

Description of tools used for managed pressure drilling (Todd et al.,2006 ${ }^{1}$, Malloy et al.,20082 , Tercan 2010³)

\begin{tabular}{|c|c|c|}
\hline Tools & Types & \\
\hline $\begin{array}{l}\text { Device } \\
\text { (RCD) }\end{array}$ & $\begin{array}{l}\text { 2. Rotating Control } \\
\text { Device on Fixed } \\
\text { Rigs (no wave } \\
\text { heave) } \\
>\quad \text { Passive \& } \\
\text { Active annular } \\
\text { seal design } \\
\text { "land" models } \\
>\text { Marine Diverter } \\
\text { Converter RCD } \\
\text { Bell Nipple } \\
\text { Insert RCD } \\
\text { IRRCH (in } \\
\text { marine diverter } \\
\text { or surface }\end{array}$ & 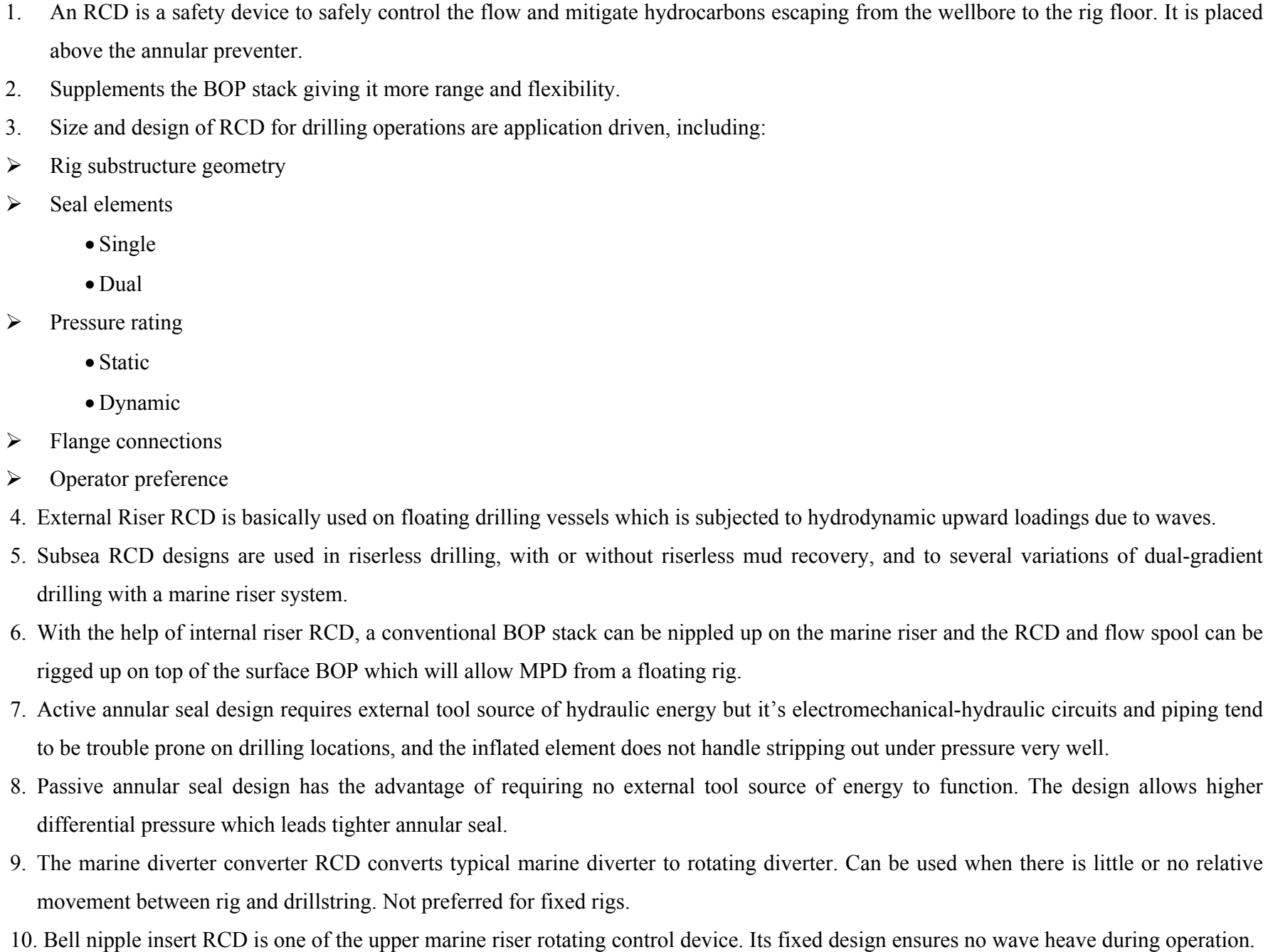 \\
\hline
\end{tabular}




\begin{tabular}{|c|c|c|}
\hline & annular) & \\
\hline Rig pump diverter & & 1. It supplies and maintains back pressure during drill pipe connections using the flow provided by the mud pumps of the rig \\
\hline Choke & $\begin{array}{ll}\text { 1. } & \text { Manual } \\
\text { 2. } & \text { Semi-automatic } \\
\text { 3. } & \text { PC Controlled } \\
\text { Automatic }\end{array}$ & $\begin{array}{l}\text { 1. Choke is must for CBHP operations and should be installed in the return flow line to allow back pressure the drilling process along with } \\
\text { a separate MPD choke manifold. The manual choke transmission of data and remote visualization can be done through internet } \\
\text { connectivity at the wellsite. } \\
\text { 2. Automated choke systems are more preferable to eliminate human error while using the system in narrow pressure window situations } \\
\text { like in MPD. } \\
\text { 3. Semi-automatic chokes are also used which are capable of automatic surface back pressure control. Theadvantages of using semi- } \\
\text { automatic choke are: } \\
\text { • maintaining stable BHP during connections } \\
\text { • instantaneous change in BHP compared to increasing mud weight } \\
\text { • improving kick detection } \\
\text { • coptinuing drilling through High Pressure Low Volume (HPLV) nuisance gas zones } \\
\text { - reducing effect of gas-cut mud } \\
\text { Fully automated choke system iscapable of automatic control of any pressure variable desired such as BHP, stand pipe pressure (SPP), } \\
\text { and surface back pressure (SBP). They are commonly used in CBHP applicationswhile making up new connections in order to prevent } \\
\text { pressure related drilling hazards. The concept is applying back pressure by closing the choke manifold to compensate reduction of AFP } \\
\text { while gradually decreasing the pump rate. It includes mass flow meter, precision quartz pressure sensors, Hydraulic Power Unit (HPU), } \\
\text { and Intelligent Control Unit (ICU). All the critical controls, algorithms and data acquisition are installed at the manifold, to avoid any } \\
\text { potential problem with communication and to increase the reliability of the system }\end{array}$ \\
\hline Mass Flow Meter & & $\begin{array}{l}\text { 1. The mass flow meter is installed at the manifold, just downstream the chokes for mass flow and density measurements. Measuring } \\
\text { principle is based on control generation of Coriolis forces. Measurements have accuracy of the order of } 0.15 \% \text { of reading. }\end{array}$ \\
\hline Back Pressure Pump & & 1. To supply and maintain back pressure during low-flow or pumps-off events like on drillpipe connections. \\
\hline Non-Return Valves & $\begin{array}{l}\text { 1. Basic Piston type } \\
\text { Float } \\
\text { 2. Hydrostatic } \\
\text { Control Valve }\end{array}$ & $\begin{array}{l}\text { 1. The non-return valve, or one-way valve in the drillpipe, was originally called a float. ConsideringU-tube principleit is evident that any } \\
\text { positive unbalance in the annulus forces will push drilling fluid with cuttings back up the drillpipe which can plug the motor or MWD } \\
\text { or, in the worst case, blow out the drillpipe. Therefore, NRV is a key in MPD applications to prevent backflow inside the drillstring. } \\
\text { 2. The primary line of defence against backflow problems has been the type-G Baker float, also called piston float. It has a simple piston }\end{array}$ \\
\hline
\end{tabular}




\begin{tabular}{|c|c|c|}
\hline & 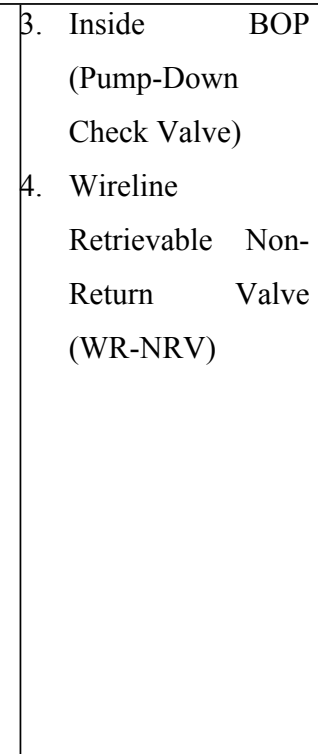 & $\begin{array}{l}\text { driven closed by a spring that looks a bit like an engine valve system. Drilling fluid pressure forces the valve open against the spring } \\
\text { when circulating; and when the pump is turned off, the spring and any well bore pressure force the valve to get closed. But the problem } \\
\text { with G float is that it blocks the drillpipe for wireline and blocks SIDPPduring well kick situation. } \\
\text { 3. The hydrostatic control valve (HCV) is a subsea version of the bit float valve used in dual gradient drilling. It is used to hold up a } \\
\text { column of drilling fluid in the drillpipe to avoid the U-tube effect when the pump is turned off. It also restricts the use of an NRV at the } \\
\text { bit to prevent backflow and plugging. } \\
\text { 4. The inside BOP is designed as a pump-down tool seated in a sub above the bottom hole assembly and acting as a check valve against } \\
\text { upward flow. It is now used as a backup to the bit float. It can be installed on the float valve and the entire assembly is kept ready on the } \\
\text { rig floor for quick installation at the first signs of serious backflow during tripping out of the hole. } \\
\text { Wireline Retrievable Non-Return Valve is a newly introduced NRV type which is placed in the drillstring; this flapper-style drill-float } \\
\text { valve prevents pressure from entering the string above it. It enhances safety by allowing pressure above the valve in the drillstring to be } \\
\text { bleed off when making and breaking connections. Keyadvantagesof WR-NRV are as follows: } \\
\text { - WR-NRV can be changed or removed without tripping the drillstring or killing the well which saves rig time \& money. } \\
\text { - Designed for high-pressure applications. }\end{array}$ \\
\hline Accessory tools & 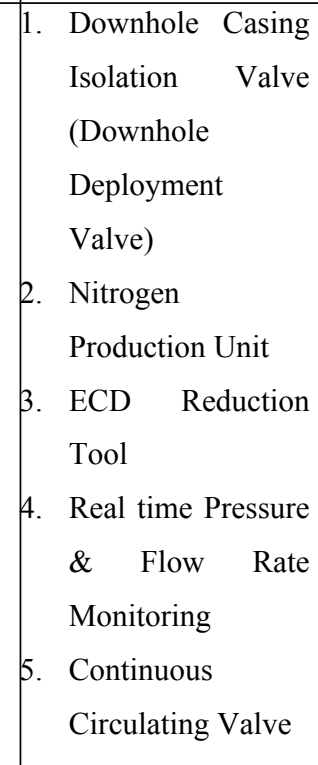 & $\begin{array}{l}\text { 1. Downhole Deployment Valve (DDV) is a downhole valve which allows tripping without killing the well. It is opened and closed by } \\
\text { equalizing the pressures below and above the tool. } \\
\text { 2. Advantages of Downhole Deployment Valve (DDV) are: } \\
\text { • Formation damage is minimized. } \\
\text { - Eliminates time required to circulate kill fluid. } \\
\text { - Protect against potential swabbing and kick while tripping. } \\
\text { - No fluid loss. } \\
\text { - Eliminates the need for snubbing operations, enhancing safety. } \\
\text { - Installation of assemblies such as whipstocks, slotted liners, and expandable sand screens can be done with ease. } \\
\text { Some limitations of Downhole Deployment Valve are: } \\
\text { - DDV contains elastomeric seals that can deteriorate over time when exposed to well effluent during production. } \\
\text { - The hole size or previous casings needs to be a size larger. } \\
\text { - Pressure limits on the tool must be considered. } \\
\text { - The umbilical cord must be protected during cementing, which may limit pipe reciprocation. }\end{array}$ \\
\hline
\end{tabular}




\begin{tabular}{|c|c|c|}
\hline & $\begin{array}{l}\text { 6. Continuous } \\
\text { Circulating System } \\
\text { 7. Downhole air } \\
\text { diverter } \\
\text { 8. Multiphase } \\
\text { Separation Unit }\end{array}$ & $\begin{array}{l}\text { 3. The Downhole Air Diverter (DHAD) is a drillpipe or drill collar sub equipped with two sonic nozzle valves strategically placed in the } \\
\text { drillstring to divert a portion of the compressed pneumatic fluid from inside the drillstring into the annulus. Benefits of the DHAD are: } \\
\text { - Less annular bottom hole pressure. } \\
\text { - Less surface drill pipe pressure. } \\
\text { - Reduction or elimination of low velocity zones. } \\
\text { - Reduction of erosion potential through BHA. } \\
\text { - Reduction of downhole fire potential. } \\
\text { - Aids in use of hammer tool and flat bottom bit to control angle } \\
\text { 4. Nitrogen Production Units (NPU) produces nitrogen from air using a filtering process. These systems are best used for remote locations } \\
\text { where the cost of delivered liquid nitrogen is high, time consuming and requirements are high. NPU is compulsory in Dual Gradient } \\
\text { MPD applications where there is a need for continuous supply of nitrogen to reduce the upper riser mud density. } \\
\text { 5. Multiphase Separation System is also compulsory in Dual Gradient MPD applications where the separation of gas is an obvious issue or } \\
\text { can be used in case of any influx to condition the mud. }\end{array}$ \\
\hline
\end{tabular}




\section{Table S2}

Characteristics of gas hydrate saturated Indian offshore basins ( Sethuraman Ramesh, ISNGIIT Madras 20194)

\begin{tabular}{|l|c|c|c|}
\hline \multirow{2}{*}{ Property } & \multicolumn{3}{|c|}{ Reservoir } \\
\cline { 2 - 4 } & KG basin & Mahanadi & Andaman \\
\hline Location & NGHP-01-10D & NGHP-01-19D & NGHP-01-17A \\
\hline Water depth(m) & 1030 & 1422 & 1344 \\
\hline Thickness(m) & 120 & 25 & 23 \\
\hline Formation pressure(bar) & 107 & 160 & 165 \\
\hline Associated reservoir & Smectite clay & Very fine silt & Volcanic tuff \\
\hline Median grain size $(\mu \mathrm{m})$ & 5.8 & 4.8 & 5.1 \\
\hline Formation depth (mbsf) & 40 & 200 & 500 \\
\hline Temperature (based on geothermal gradient) & $9{ }^{\circ} \mathrm{C}$ & $16.2^{\circ} \mathrm{C}$ & $10.6^{\circ} \mathrm{C}$ \\
\hline Porosity & $60^{\circ} \%$ & $65^{\circ} \%$ & $60^{\circ}$ \\
\hline Hydrate saturation in $\%$ & $90 \%$ & $15 \%$ & $20 \%$ \\
\hline Thermal conductivity in w/m-k & 0.6 & 0.85 & 0.8 \\
\hline Rock matrix density in kg/m3 & 2750 & 2690 & 2500 \\
\hline Hydrate bearing zone resistivity in $\Omega$-m & 100 & 2.5 & 2.2 \\
\hline
\end{tabular}




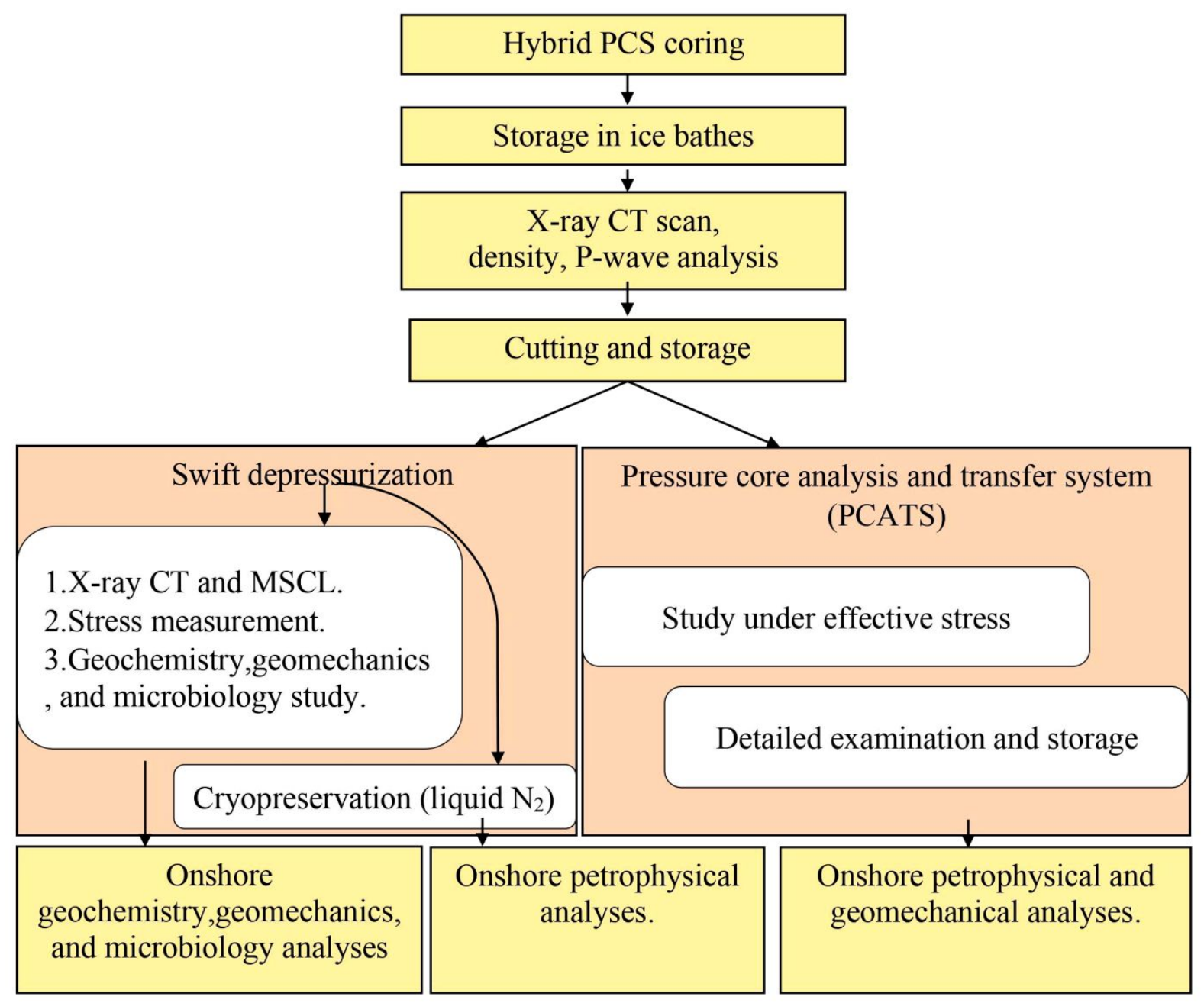

Figure S1. Schematic flow of onboard core processing (Adapted from Kubo et al.,20145) 


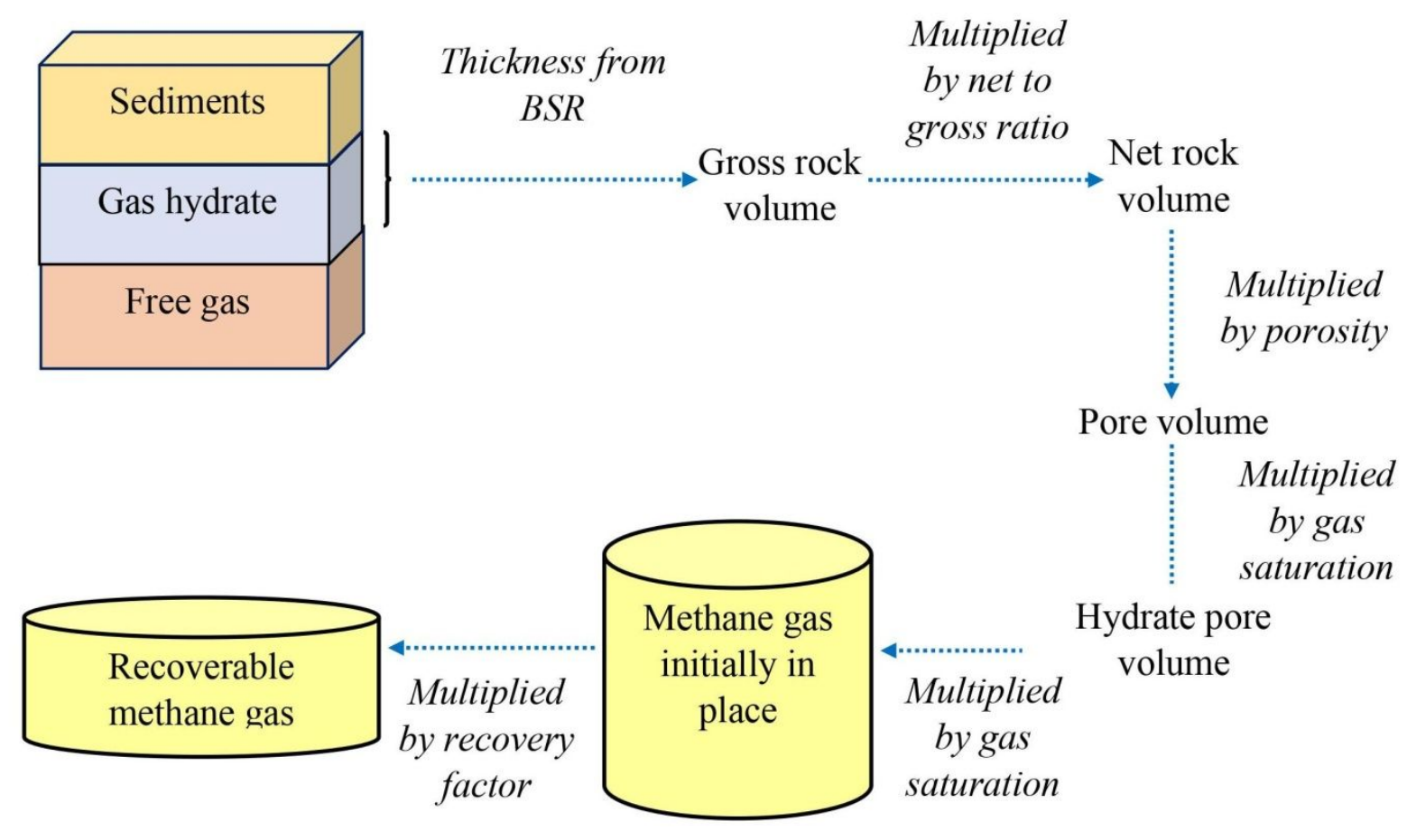

Figure S2. Steps involved in reserve calculation for hydrate reservoir (Adapted from Kim Senger et al. ${ }^{6}$ )

\section{REFERENCES}

(1) Todd, R. J.; Hannegan, D. M.; Harrall, S. New Technology Needs for Methane Hydrates Production; Offshore Technology Conference, 2006. https://doi.org/https://doi.org/10.4043/18247-MS.

(2) Malloy, K. P.; McDonald, P. A Probabilistic Approach to Risk Assessment of Managed Pressure Drilling in Offshore Applications; 2008.

(3) Tercan, E. Managed Pressure Drilling Techniques, Equipment \& Applications, Middle East Technical University, 2010.

(4) Sethuraman, R. International Symposium on Natural Gas Value Chain.Lecture,IIT Madras,India,10 ${ }^{\text {th }}$ December 2019.

(5) Kubo, Y.; Mizuguchi, Y.; Inagaki, F.; Yamamoto, K. A New Hybrid Pressure-Coring System for the Drilling Vessel Chikyu. Sci. Drill. 2014, 17 (17), 37-43. 
https://doi.org/10.5194/sd-17-37-2014.

(6) Senger, K.; Bünz, S.; Mienert, J. First-Order Estimation of In-Place Gas Resources at the Nyegga Gas Hydrate Prospect, Norwegian Sea. Energies 2010, 3 (12), 2001-2026. https://doi.org/10.3390/en3122001. 